\title{
Corn silage in dairy cow diets to reduce ruminal methanogenesis: Effects on the rumen metabolically active microbial communities
}

\author{
A. Lettat, F. Hassanat, and C. Benchaar ${ }^{1}$ \\ Agriculture and Agri-Food Canada, Dairy and Swine Research and Development Centre, 2000 College Street, Sherbrooke, Quebec, \\ Canada J1M 0C8
}

\begin{abstract}
Methane produced by the methanogenic Archaea that inhabit the rumen is a potent greenhouse gas and represents an energy loss for the animal. Although several strategies have been proposed to mitigate enteric $\mathrm{CH}_{4}$ production, little is known about the effects of dietary changes on the microbial consortia involved in ruminal methanogenesis. Thus, the current study aimed to examine how the metabolically active microbes are affected when dairy cows were fed diets with increasing proportions of corn silage (CS). For this purpose, 9 ruminally cannulated lactating dairy cows were used in a replicated $3 \times 3$ Latin square design and fed a total mixed ration (60:40 forage:concentrate ratio on a dry matter basis) with the forage portion being either alfalfa silage $(0 \% \mathrm{CS})$, corn silage $(100 \% \mathrm{CS})$, or a 50:50 mixture (50\% CS). Enteric $\mathrm{CH}_{4}$ production was determined using respiration chambers and total rumen content was sampled for the determination of fermentation characteristics and molecular biology analyses (cDNA-based length heterogeneity PCR, quantitative PCR). The cDNA-based length heterogeneity PCR targeting active microbes revealed similar bacterial communities in cows fed $0 \% \mathrm{CS}$ and $50 \%$ CS diets, whereas important differences were observed between 0\% CS and $100 \%$ CS diets, including a reduction in the bacterial richness and diversity in cows fed $100 \%$ CS diet. As revealed by quantitative PCR, feeding the $100 \%$ CS diet increased the number of total bacteria, Prevotella spp., Archaea, and methanogenic activity, though it reduced protozoal number. Meanwhile, increasing the CS proportion in the diet increased propionate concentration but decreased ruminal $\mathrm{pH}, \mathrm{CH}_{4}$ production (L/ $\mathrm{kg}$ of dry matter intake), and concentrations of acetate and butyrate. Based on these microbial and fermentation changes, and because $\mathrm{CH}_{4}$ production was reduced by feeding $100 \%$ CS diet, this study shows that the use of cDNA-based quantitative PCR to estimate archaeal
\end{abstract}

Received December 13, 2012.

Accepted April 30, 2013.

${ }^{1}$ Corresponding author: chaouki.benchaar@agr.gc.ca growth and activity is not reliable enough to reflect changes in ruminal methanogenesis. A more robust technique to characterize changes in archaeal community structures will help to better understand the microbial process involved in ruminal methanogenesis and, hence, enabling the development of more effective dietary $\mathrm{CH}_{4}$ mitigation strategies.

Key words: corn silage, alfalfa silage, ruminal methanogenesis, rumen microbe

\section{INTRODUCTION}

In ruminants, enteric $\mathrm{CH}_{4}$ production is the result of $\mathrm{CO}_{2}$ reduction by the methanogenic Archaea that use the hydrogen resulting from the anaerobic microbial fermentation of feeds. Methane is a potent greenhouse gas and represents about $25 \%$ of the annual anthropogenic $\mathrm{CH}_{4}$ emitted into the atmosphere (Lassey, 2008). Moreover, methanogenesis is an energy waste for the ruminant, representing 2 to $12 \%$ of gross energy intake (Martin et al., 2010; Benchaar and Greathead, 2011). The level of $\mathrm{CH}_{4}$ emission is mainly determined by feed intake and the composition of the diet (Boadi et al., 2004; Martin et al., 2010).

Because of its environmental and nutritional concern, several dietary strategies have been suggested to mitigate enteric $\mathrm{CH}_{4}$ emissions from ruminants (Martin et al., 2010). It is well known that starch fermentation in the rumen favors propionate production at the expense of acetate and decreases ruminal $\mathrm{pH}$, which reduces hydrogen availability and inhibits the activity of rumen methanogens (Martin et al., 2010; Hook et al., 2011a). Rumen protozoal numbers are also often decreased in ruminants fed high-starch diets, which also reduces the transfer of hydrogen from protozoa to methanogens (Morgavi et al., 2012). Compared with alfalfa silage (AS), corn silage (CS) contains higher amounts of starch, which make it an interesting means to reduce enteric $\mathrm{CH}_{4}$ production.

Because of the symbiotic relationship between the ruminant and its microbiota, a greater understanding of how dietary changes affect the microbial consortia, especially the interactions between Archaea and other 
microorganisms, will enable the development of more robust mitigation strategies. So far, microbial quantification in the rumen was assessed by targeting DNA (Zhou et al., 2009; Lettat et al., 2012), which is not a reliable marker for metabolically active microbes because extracted DNA may arise from dead bacteria or bacteria in a dormant state, which are not implicated in the fermentation processes (Sheridan et al., 1998; de la Cruz-Leyva et al., 2011). On the contrary, RNA is more correlated with microbial growth rate and metabolic activity (Sheridan et al., 1998; de la Cruz-Leyva et al., 2011). Hence, its utilization is thought to be more reliable to quantify rumen microbial populations.

In a companion paper (Hassanat et al., 2013), we observed lower $\mathrm{CH}_{4}$ energy losses in dairy cows when CS replaced AS in the diet. This was associated with lower ruminal $\mathrm{pH}$, decreased protozoa numbers, and increased propionate proportion at the expense of acetate, suggesting possible shifts in microbial populations involved in substrate fermentation and $\mathrm{CH}_{4}$ formation within the rumen. Therefore, the objective of this study was to examine the effects of replacing AS with CS in dairy cow diets on the metabolically active ruminal microbial communities (bacteria, Archaea, protozoa). This study also aimed to assess the reliability of length heterogeneity-PCR (LH-PCR) to fingerprint the bacteria and Archaea communities within the rumen.

\section{MATERIALS AND METHODS}

All animal procedures were conducted under the approval of the Animal Care Committee of the Dairy and Swine Research and Development Center (Sherbrooke, Canada) and were in accordance with the guidelines of the Canadian Council on Animal Care (1993).

Experimental details (cows, diets, rumen content collection for the determination of $\mathrm{pH}$ and VFA, $\mathrm{CH}_{4}$ measurements) of the present study have been described in a companion paper (Hassanat et al., 2013) and, therefore, will be briefly described in this section.

\section{Dairy Cows and Diets}

Nine multiparous Holstein lactating cows fitted with ruminal cannulas $(10 \mathrm{~cm}$, Bar Diamond Inc., Parma, ID) were used in a replicated $3 \times 3$ Latin square $(31$-d period). The cows averaged (mean $\pm \mathrm{SD}) 688 \pm 66 \mathrm{~kg}$ of BW, $82 \pm 18 \mathrm{DIM}$, and $41 \pm 4 \mathrm{~kg} / \mathrm{d}$ of milk at the start of the experiment. They were fed a TMR (60:40 forage:concentrate ratio) twice daily (0900 and $1930 \mathrm{~h}$ ) for ad libitum intake, with the forage portion being either alfalfa silage $(\mathbf{0 \%} \mathbf{C S})$, corn silage $(\mathbf{1 0 0 \%} \mathbf{C S})$ or a 50:50 mixture $(\mathbf{5 0 \%} \mathbf{C S})$. The cows were kept in individual stalls and had free access to water. Ingredient and chemical composition of the diets are shown in Table 1. More details on dairy cows and experimental diets are provided in a companion paper (Hassanat et al., 2013).

\section{Rumen Fluid Collection for $\mathrm{pH}$ and VFA Determination}

Sampling for the measurement of ruminal $\mathrm{pH}$ and VFA concentrations was performed as described in Benchaar et al. (2012). Briefly, ruminal fluid was collected from the anterior dorsal, anterior ventral, medium ventral, posterior dorsal, and posterior ventral locations within the rumen at 0 (i.e., before feeding), $1,2,4,6$, and $8 \mathrm{~h}$ after the morning feeding. Samples $(250 \mathrm{~mL} /$ site) were withdrawn using a syringe screwed to a stainless tube ending with a probe covered by a fine metal mesh (RT Rumen Fluid Collection Tube, Bar Diamond Inc.). Ruminal fluid $\mathrm{pH}$ was measured immediately after sampling (Accumet $\mathrm{pH}$ meter; Fisher

Table 1. Ingredient and chemical composition of the experimental diets

\begin{tabular}{lccc}
\hline & \multicolumn{3}{c}{ Treatment $^{1}$} \\
\cline { 2 - 3 } Item & $0 \%$ CS & $50 \%$ CS & $100 \%$ CS \\
\hline Ingredient (\% of DM) & & & \\
Corn silage & 0.0 & 28.2 & 56.4 \\
Alfalfa silage & 56.4 & 28.2 & 0 \\
Grass hay & 3.2 & 3.2 & 3.2 \\
Concentrate & 37.7 & 37.5 & 2.8 \\
Mineral and vitamin supplement & 2.8 & 2.8 & 2.8 \\
Chemical composition (\% of DM) & 91.7 & 92.8 & 17.0 \\
OM & 23.4 & 20.2 & 15.6 \\
ADF & 16.8 & 22.8 & 30.0 \\
CP & 17.0 & & \\
Starch & &
\end{tabular}


Scientific, Montreal, Canada), and samples were acidified to $\mathrm{pH} 2$ with $50 \% \mathrm{H}_{2} \mathrm{SO}_{4}$ and frozen at $-20^{\circ} \mathrm{C}$ for later determination of VFA concentrations as described in Hassanat et al. (2013).

\section{Methane Production Measurement}

Enteric $\mathrm{CH}_{4}$ production was determined over 3 consecutive days using 2 air-flow-controlled chambers (1 animal/chamber). The measurements were based on the mass-balance approach, which consists of measuring flows of the air and the concentrations of $\mathrm{CH}_{4}$ entering and leaving the chamber, and the difference between the incoming and the outgoing mass (i.e., air flow $\times$ concentration) of $\mathrm{CH}_{4}$ was used to calculate the amount generated in the chamber by the animal. More details on enteric $\mathrm{CH}_{4}$ measurements are given in the companion paper (Hassanat et al., 2013).

\section{Rumen Sample Collection for RNA Extraction and cDNA Synthesis}

Before $(0 \mathrm{~h})$ and $4 \mathrm{~h}$ after the morning feeding, $\sim 2 \mathrm{~kg}$ of total ruminal content were collected from 5 different sites within the rumen. After manual homogenization, $\sim 25 \mathrm{~g}$ of ruminal content were homogenized in ice using a PT 10/35 Polytron homogenizer (Kinematica GmbH, Bohemia, NY) at speed 6 , for two 1-min cycles with 1 min of rest between cycles. Subsequently, representative aliquots of $1.5 \mathrm{~g}$ were stored at $-80^{\circ} \mathrm{C}$ until RNA extraction. For each sampling time, samples of ruminal content were dried at $100^{\circ} \mathrm{C}$ for $72 \mathrm{~h}$ for DM determination.

Total RNA was recovered from frozen samples using the FastRNA Spin Kit (MP Biomedicals, Solon, OH) as previously described (Lettat et al., 2012) with minor modifications. Briefly, $\sim 250 \mathrm{mg}$ of frozen ruminal content were weighed into the provided tubes containing silica beads. For cell lysis, samples were subjected twice to a 1-min pulse, with 2 min of cooling at $4^{\circ} \mathrm{C}$ between the 2 pulses, using the Mini-Beadbeater-8 (BioSpec Products, Bartlesville, OK). The yield and the purity of the extracted RNA were assessed by optical density measurement with the NanoDrop ND-1000 spectrophotometer (Thermo Fisher Scientific, Wilmington, DE). Absorbance intensity at $260 \mathrm{~nm}$ was used to assess the concentration of RNA in $1 \mu \mathrm{L}$ of sample, whereas sample purity was checked at 260:280 and 260:230 ratios.

For cDNA synthesis, extracted RNA was reverse transcribed using the AMV reverse transcriptase (Promega, Madison, WI) according to the manufacturer's instructions with minor modifications. Briefly, $1 \mu \mathrm{g}$ of RNA was mixed with $0.5 \mu \mathrm{g}$ of random primers in a 15$\mu \mathrm{L}$ final volume and the mixture was brought to $70^{\circ} \mathrm{C}$ for 5 min followed by 10 min on ice to allow annealing. Then, a $25-\mu \mathrm{L}$ buffer mixture containing $1 \times$ AMV buffer, $1 \mu M$ of each dNTP, 1.6 U of RNasin and 3.6 $\mathrm{U}$ of AMV reverse transcriptase (Promega) was added. Reverse transcription was carried out at $37^{\circ} \mathrm{C}$ for $1 \mathrm{~h}$ using the C1000 thermal cycler (Bio-Rad Laboratories, Mississauga, Canada).

\section{Bacteria and Archaea Quantification by Quantitative PCR}

In this study, we quantified methanogenic Archaea, total bacteria, and specific bacteria that were selected based on their role in ruminal fermentation processes (i.e., starch and fiber degradation) and the utilization or production of hydrogen. The examined bacteria included Prevotella genus, which is the dominant amylolytic bacterial group and an efficient hydrogen utilizer for propionate production; the lactate-utilizing and propionate-producing bacterium Megasphaera elsdenii; the cellulolytic bacteria Fibrobacter succinogenes, a nonhydrogen-producing organism; and Ruminococcus albus, a hydrogen producing bacterium (ChaucheyrasDurand et al., 2010).

The SYBR green chemistry-based quantitative PCR was carried out using the 7500 Fast System (Applied Biosystems, Mississauga, Canada). Total and selected bacteria were quantified by targeting the small ribosomal subunit (rrs) RNA (Lettat et al., 2012), whereas the rrs and methyl coenzyme-M reductase ( $\boldsymbol{m} \boldsymbol{c r} \boldsymbol{A})$ RNA were used for methanogenic Archaea detection (Mosoni et al., 2011). In a $20-\mu \mathrm{L}$ total volume, the quantitative PCR mixture was composed of $0.75 \times$ SYBR Premix Ex TaqII (Clontech Laboratories Inc., Madison, WI), $40 \mathrm{ng}$ of cDNA template, and $0.25 \mu \mathrm{M}$ of each forward and reverse primer, except for Archaea and Prevotella for which 0.3 and $0.5 \mu M$ were used, respectively. Each reaction was run in triplicate in 96-well plates (Applied Biosystems). The primer sequences and amplification programs used are summarized in Tables 2 and 3. An absolute quantification of the bacteria was performed using specific rrs DNA standards from $R$. albus 7 (ATCC 27210), F. succinogenes S85 (ATCC 19169), Prevotella bryantii B14 (DSM 11371), and $M$. elsdenii (DSMZ 20460). For methanogenic Archaea, rrs and mcrA DNA standards from Methanobrevibacter smithii (DSM 861) were used. Results of quantification are expressed as $\log _{10}$ gene copies/g of DM of rumen content.

\section{Protozoa Quantification by Quantitative PCR}

The ruminal protozoa were quantified by targeting the $18 \mathrm{~S}$ rRNA in the same conditions as those for 


\begin{tabular}{|c|c|c|c|c|}
\hline Target & Primer set & Primer sequence $5^{\prime}-3^{\prime}$ & Used for ${ }^{1}$ & Source \\
\hline \multirow[t]{2}{*}{ Bacteria } & $520-\mathrm{F}$ & AGC AGC CGC GGT AAT & qPCR & (Edwards et al., 2007) \\
\hline & 799-R2 & CAG GGT ATC TAA TCC TGT T & $\mathrm{qPCR}$ & \\
\hline \multirow{2}{*}{ Prevotella spp. } & gPrevo-F & CAC RGT AAA CGA TGG ATG CC & $\mathrm{qPCR}$ & (Bekele et al., 2010) \\
\hline & gPrevo-R & GGT CGG GTT GCA GAC C & $\mathrm{qPCR}$ & \\
\hline \multirow[t]{2}{*}{ Fibrobacter succinogenes } & FibSuc3-F & GCG GGT AGC AAA CAG GAT TAG A & qPCR & (Stevenson and Weimer, 2007) \\
\hline & FibSuc3-R & CCC CCG GAC ACC CAG TAT & $\mathrm{qPCR}$ & \\
\hline \multirow[t]{2}{*}{ Ruminococcus albus } & RumAlb3-F & TGT TAA CAG AGG GAA GCA AAG CA & $\mathrm{qPCR}$ & (Stevenson and Weimer, 2007) \\
\hline & RumAlb3-R & TGC AGC CTA CAA TCC GAA CTA A & $\mathrm{qPCR}$ & \\
\hline \multirow[t]{2}{*}{ Megasphaera elsdenii } & MegEls1-F & GAC CGA AAC TGC GAT GCT AGA & $\mathrm{qPCR}$ & (Ozutsumi et al., 2006) \\
\hline & MegEls1-R & CGC CTC AGC GTC AGT TGT & $\mathrm{qPCR}$ & \\
\hline \multirow{2}{*}{ Archaea $(r r s)^{2}$} & $1174-\mathrm{F}$ & GAG GAA GGA GTG GAC GAC GGT A & $\mathrm{qPCR}$ & (Ohene-Adjei et al., 2008) \\
\hline & $1406-1389-\mathrm{R}$ & ACG GGC GGT GTG TGC AAG & qPCR & \\
\hline \multirow[t]{2}{*}{$\operatorname{Archaea}(m c r A)^{3}$} & qmerA-F & TTC GGT GGA TCD CAR AGR GC & qPCR & (Denman et al., 2007) \\
\hline & qmerA-R & GBA RGT CGW AWC CGT AGA ATC C & qPCR & \\
\hline \multirow[t]{2}{*}{ Protozoa } & $316-\mathrm{F}$ & GCT TTC GWT GGT AGT GTA TT & $\mathrm{qPCR}$ & (Sylvester et al., 2004) \\
\hline & $539-\mathrm{R}$ & CTT GCC CTC YAA TCG TWC T & qPCR & \\
\hline \multirow{2}{*}{ Bacteria } & $27-\mathrm{F}$ & 6FAM-AGA GTT TGA TCM TGG CTC AG & LH-PCR & (Suzuki et al., 1998) \\
\hline & $355-\mathrm{R}$ & GCT GCC TCC CGT AGG AGT & LH-PCR & \\
\hline \multirow[t]{2}{*}{ Archaea } & mcrA-F & 6FAM-GGT GTM GGD TTC ACH CAR TAY GC & LH-PCR & (Gagnon et al., 2011) \\
\hline & mcrA-R & TTC ATN GCR TAG TTH GGR TAG TT & LH-PCR & \\
\hline
\end{tabular}

${ }^{1} \mathrm{qPCR}=$ quantitative PCR; LH-PCR = length heterogeneity-PCR.

${ }^{2}$ rrs $=$ small ribosomal subunit.

${ }^{3} \mathrm{mcr} A=$ methyl coenzyme-M reductase.

Table 3. Amplification programs used for quantitative PCR (qPCR), length heterogeneity-small ribosomal subunit (LH-rrs), and length heterogeneity-methyl coenzyme-M reductase $(\mathrm{LH}-\mathrm{mcr} A)$

\begin{tabular}{|c|c|c|c|c|c|c|}
\hline Assay & Target & $\begin{array}{l}\text { Initial } \\
\text { heating }\end{array}$ & Denaturation & $\begin{array}{l}\text { Annealing } \\
\text { or elongation }\end{array}$ & $\begin{array}{l}\text { Final } \\
\text { extension }\end{array}$ & $\begin{array}{c}\text { PCR efficiency } \\
(\%)\end{array}$ \\
\hline \multirow{8}{*}{$\mathrm{qPCR}$} & Bacteria & $95^{\circ} \mathrm{C}, 10 \mathrm{~s}$ & $95^{\circ} \mathrm{C}, 15 \mathrm{~s}$ & $58^{\circ} \mathrm{C}, 1 \min$ & - & 92 \\
\hline & Prevotella & $95^{\circ} \mathrm{C}, 10 \mathrm{~s}$ & $95^{\circ} \mathrm{C}, 15 \mathrm{~s}$ & $55^{\circ} \mathrm{C}, 5 \mathrm{~s}$ then $72^{\circ} \mathrm{C}, 30 \mathrm{~s}$ & - & 95 \\
\hline & Fibrobacter succinogenes & $95^{\circ} \mathrm{C}, 10 \mathrm{~s}$ & $95^{\circ} \mathrm{C}, 15 \mathrm{~s}$ & $60^{\circ} \mathrm{C}, 30 \mathrm{~s}$ & - & 102 \\
\hline & Ruminococcus albus & $95^{\circ} \mathrm{C}, 10 \mathrm{~s}$ & $95^{\circ} \mathrm{C}, 15 \mathrm{~s}$ & $60^{\circ} \mathrm{C}, 30 \mathrm{~s}$ & - & 92 \\
\hline & Megasphaera elsdenii & $95^{\circ} \mathrm{C}, 10 \mathrm{~s}$ & $95^{\circ} \mathrm{C}, 15 \mathrm{~s}$ & $60^{\circ} \mathrm{C}, 30 \mathrm{~s}$ & - & 92 \\
\hline & Archaea $(r r s)$ & $95^{\circ} \mathrm{C}, 10 \mathrm{~s}$ & $95^{\circ} \mathrm{C}, 15 \mathrm{~s}$ & $63^{\circ} \mathrm{C}, 15 \mathrm{~s}$ then $72^{\circ} \mathrm{C}, 30 \mathrm{~s}$ & - & 100 \\
\hline & Archaea $(m c r A)$ & $50^{\circ} \mathrm{C}, 2 \mathrm{~min}$ then $95^{\circ} \mathrm{C}, 1 \mathrm{~min}$ & $95^{\circ} \mathrm{C}, 15 \mathrm{~s}$ & $60^{\circ} \mathrm{C}, 1 \mathrm{~min}$ & & 99.5 \\
\hline & Protozoa & $95^{\circ} \mathrm{C}, 10 \mathrm{~s}$ & $95^{\circ} \mathrm{C}, 15 \mathrm{~s}$ & $60^{\circ} \mathrm{C}, 30 \mathrm{~s}$ & - & 92 \\
\hline LH-rrs & Bacteria & $94^{\circ} \mathrm{C}, 2 \min$ & $94^{\circ} \mathrm{C}, 1 \min$ & $55^{\circ} \mathrm{C}, 1 \mathrm{~min}$ then $72^{\circ} \mathrm{C}, 1 \mathrm{~min}$ & $72^{\circ} \mathrm{C}, 20 \min$ & - \\
\hline LH-mcrA & Archaea & $94^{\circ} \mathrm{C}, 2 \mathrm{~min}$ & $94^{\circ} \mathrm{C}, 1 \mathrm{~min}$ & $55^{\circ} \mathrm{C}, 1.30 \mathrm{~min}$ then $72^{\circ} \mathrm{C}, 1 \mathrm{~min}$ & $72^{\circ} \mathrm{C}, 20 \mathrm{~min}$ & - \\
\hline
\end{tabular}


bacteria and Archaea, using $0.25 \mu M$ of each forward and reverse primer (Tables 2 and 3). An absolute quantification was made using $18 \mathrm{~S}$ rRNA standards prepared as described in Sylvester et al. (2004) and total protozoal DNA extracted from fresh protozoal preparations. Briefly, protozoa were counted microscopically (Neubauer Improved Bright-Line counting cell, $0.1 \mathrm{~mm}$ depth; Hausser Scientific, Horshamm, PA) and then were diluted to a range of $1.2 \times 10^{6}$ to $1.2 \times$ $10^{2}$ cells $/ \mathrm{mL}$. Genomic DNA was extracted using the FastDNA Spin Kit (MP Biomedicals) according to the manufacturer instructions and was used as a standard for protozoa quantification. The results were expressed as $\log _{10} 18 \mathrm{~S}$ rRNA copies or $\log _{10}$ cells/g of DM. Only quantitative PCR assays that fell within the range of 90 to $110 \%$ of efficiency and that showed $\mathrm{R}^{2} \geq 0.99$ were considered for further analysis.

\section{LH-PCR Fingerprints of Bacteria (rrs Gene) and Archaea (mcrA Gene)}

Length heterogeneity-PCR based on natural length variations in the rrs (LH-rrs) and mcrA (LH-mcrA) genes was used to fingerprint the bacterial (Suzuki et al., 1998) and archaeal communities (Gagnon et al., 2011). Briefly, in a final volume of $25 \mu \mathrm{L}$, the LH-rrs and LH-mcrA mixtures were composed of $40 \mathrm{ng}$ of cDNA template, $0.5 \mu M$ of each forward and reverse primer (Applied Biosystems), $0.1 \mathrm{~m} M$ of dNTPs (Promega), $1 \times$ Taq buffer, $1.5 \mathrm{mM}$ of $\mathrm{MgCl}_{2}$, and $0.625 \mathrm{U}$ of Taq polymerase (BioShop Inc., Burlington, Canada) in a C1000 thermal cycler (Bio-Rad Laboratories). The primer sequences and amplification programs used are summarized in Tables 2 and 3. After PCR amplification, 0- and 4-h samples were pooled and capillary electrophoresis was performed as described in Barret et al. (2012). Briefly, $1 \mu \mathrm{L}$ of template was mixed with $12.34 \mu \mathrm{L}$ of Hi-Di Formamide (Applied Biosystems) and $0.06 \mu \mathrm{L}$ of GeneScan 500 LIZ Size Standard (Applied Biosystems). The mixture was then heated at $95^{\circ} \mathrm{C}$ for 5 min and chilled on ice. Capillary electrophoresis was performed for 40 min in the GeneScan mode on an ABI Prism 310 47-cm capillary DNA sequencer using POP4 polymer (Applied Biosystems). The GeneMapper software (Applied Biosystems) was used for fingerprints analysis.

\section{Statistical Analyses}

Data were analyzed using the MIXED procedure of SAS with repeated measurements statement (SAS Institute Inc., Cary, NC). The statistical model included treatment and period as fixed effects and square and cows within square as random effects. For $\mathrm{CH}_{4}$ data, the fixed effect of the chamber was initially included in the model but was removed because it was not significant. Significant effect of treatment on least squares means was declared when $P \leq 0.05$, whereas tendencies were declared when $0.05<P \leq 0.10$. The principal component analysis (PCA) was performed on the LHPCR fingerprints using the PRINCOMP procedure of SAS using the COV option. Only the first 2 principal components were plotted. Indicator species analysis and multi-response permutation procedure were performed using the PC-ORD software (McCune and Mefford, 1999).

\section{RESULTS AND DISCUSSION}

\section{Effects of Increasing CS Proportion of the Diet on Ruminal Fermentation Pattern and $\mathrm{CH}_{4}$ Production}

As expected, feeding the $100 \%$ CS diet decreased ruminal $\mathrm{pH}$, acetate, and butyrate concentrations but increased propionate concentration (Table 4). This ruminal fermentation pattern is commonly observed in ruminants fed starch-rich diets (Benchaar et al., 2007; Khafipour et al., 2009). Methane production, expressed in liter per day, was lower for cows fed $0 \%$ CS and $100 \%$ CS diets compared with cows fed $50 \%$ CS diet. However, when expressed per kilogram of DMI to account for variation in feed intake between treatments, $\mathrm{CH}_{4}$ production was $14 \%$ lower for cows fed $100 \%$ CS compared with cows fed $0 \%$ CS and $50 \%$ CS diets. This decrease is consistent with the shift in VFA pattern toward more propionate and less acetate observed in the current study.

\section{Estimation of the Growth of the Metabolically Active Microbes}

Bacteria. In our study, we aimed to quantify the metabolically active microbes by targeting RNA instead of DNA, which, up to now, has been widely used to monitor microbial communities within the rumen (Hook et al., 2011a; Mohammed et al., 2011). Regardless the type of the diet fed to cows, the bacterial number observed in the current study was less than $4 \times 10^{9}$ rrs copies/g of DM (Table 5), which is in agreement with values reported when traditional culture methods were applied (Mackie et al., 1978; Olumeyan et al., 1986). On the contrary, the total bacteria number observed in this study is much lower than the $10^{10}$ to $10^{12} \mathrm{rrs}$ copies/g of DM classically reported when DNA was used as a marker (Mosoni et al., 2007; Lettat et al., 2012), which is surprising knowing that active cells harbor several rRNA copies. Similar to total bacteria number, Prevotella spp., F. succinogenes, R. albus, and 
Table 4. Ruminal $\mathrm{pH}$, VFA concentrations, and enteric $\mathrm{CH}_{4}$ production in lactating cows fed diets with 0,50 , or $100 \%$ corn silage (CS)

\begin{tabular}{|c|c|c|c|c|}
\hline \multirow[b]{2}{*}{ Item } & \multicolumn{3}{|c|}{ Treatment $^{1}$} & \multirow[b]{2}{*}{$\mathrm{SE}$} \\
\hline & $0 \% \mathrm{CS}$ & $50 \% \mathrm{CS}$ & $100 \%$ CS & \\
\hline \multicolumn{5}{|l|}{$\mathrm{pH}$} \\
\hline Mean & $6.26^{\mathrm{a}}$ & $6.18^{\mathrm{a}}$ & $6.03^{\mathrm{b}}$ & 0.07 \\
\hline Minimum & $6.05^{\mathrm{a}}$ & $5.95^{\mathrm{a}}$ & $5.66^{\mathrm{b}}$ & 0.09 \\
\hline $\mathrm{VFA}(\mathrm{m} M)$ & 99.6 & 97.8 & 95.0 & 4.27 \\
\hline Acetate & $66.6^{\mathrm{a}}$ & $63.4^{\mathrm{ab}}$ & $57.3^{\mathrm{b}}$ & 2.57 \\
\hline Propionate & $20.9^{\mathrm{a}}$ & $22.1^{\mathrm{a}}$ & $27.4^{\mathrm{b}}$ & 1.89 \\
\hline Butyrate & $12.1^{\mathrm{a}}$ & $12.3^{\mathrm{a}}$ & $10.2^{\mathrm{b}}$ & 0.56 \\
\hline \multicolumn{5}{|l|}{$\mathrm{CH}_{4}$} \\
\hline $\mathrm{L} / \mathrm{d}$ & $612^{\mathrm{b}}$ & $671^{\mathrm{a}}$ & $604^{\mathrm{b}}$ & 31.9 \\
\hline $\mathrm{L} / \mathrm{kg}$ of $\mathrm{DMI}$ & $28.3^{\mathrm{a}}$ & $28.8^{\mathrm{a}}$ & $24.6^{\mathrm{b}}$ & 1.14 \\
\hline
\end{tabular}

M. elsdenii numbers were also 1 to 3 log units lower than reported in previous studies based on DNA quantification (Wanapat and Cherdthong, 2009; Lettat et al., 2012).

Archaea. For Archaea, the rrs mRNA was used to estimate their number, whereas the $m c r A$ transcripts were used as a biomarker for their methanogenic activity because this gene encodes the $\alpha$-subunit of the $m c r A$, which catalyzes the last step of $\mathrm{CH}_{4}$ production by methanogens (Thauer, 1998). In the present study, mcrA transcripts were lower than those of $\operatorname{rrs}(5.32 \mathrm{vs}$. 7.94 copies/g of DM, on average; Table 5), which can be

Table 5. Ruminal microbial numbers and archaeal methanogenic activity in ruminal fluid collected before $(0 \mathrm{~h})$ and $4 \mathrm{~h}$ after feeding from lactating cows fed diets with 0,50 , or $100 \%$ corn silage (CS)

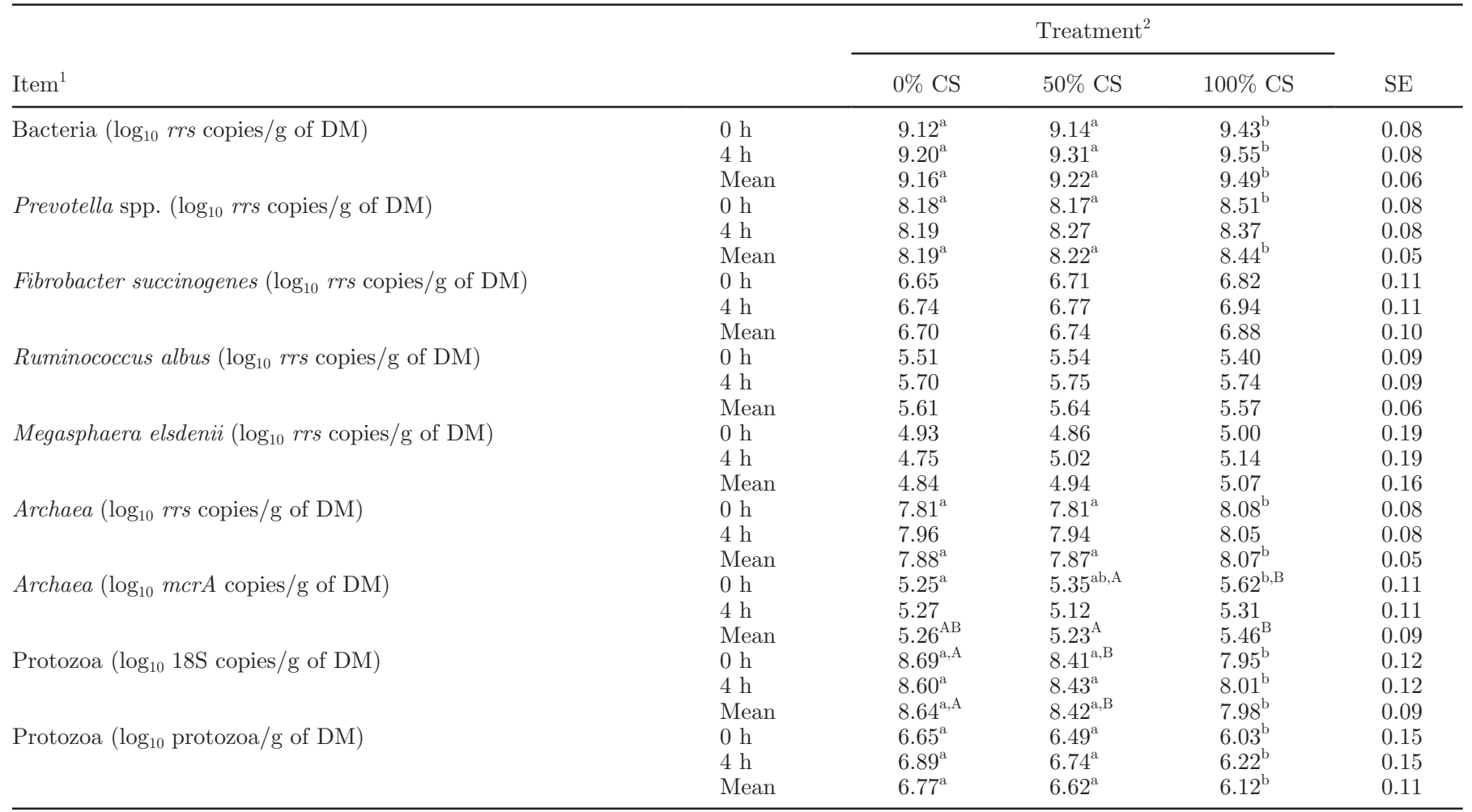

$\overline{\mathrm{a}, \mathrm{b}}$ Means in a row that do not share a common superscript differ significantly $(P \leq 0.05)$.

${ }^{\mathrm{A}, \mathrm{B}}$ Means in a row that do not share a common superscript tended $(0.05 \leq P \leq 0.10)$ to differ.

${ }^{1} \mathrm{rrs}=$ small ribosomal subunit; $\mathrm{mcr} A=$ methyl coenzyme-M reductase.

${ }^{2} 0 \% \mathrm{CS}=$ diet with $0 \%$ corn silage; $50 \% \mathrm{CS}=$ diet with $28.2 \%$ corn silage; $100 \% \mathrm{CS}=$ diet with $56.4 \%$ corn silage. 
explained by the fact that Archaea have a single copy of $m c r A$ but multiple rrs copies (Nunoura et al., 2006; Freitag and Prosser, 2009). Based on the rrs gene, the methanogenic Archaea number observed in this study is in accordance with previous reports with dairy cows (Zhou et al., 2011), heifers (Mohammed et al., 2011), steers (Zhou et al., 2009), and sheep (Mosoni et al., 2011) where DNA was used for methanogens quantification. This suggests that the methanogen community is mostly composed of living cells. On the contrary, the $m c r A$ transcripts presented here are lower than previously reported by Popova et al. (2011) in bulls $\left(1 \times 10^{9}\right.$ copies/g og DM), Mosoni et al. (2011) in sheep $(7.9 \times$ $10^{9}$ copies/g of DM), Hook et al. (2011a) in dairy cows $\left(5.4 \times 10^{6}\right.$ copies $/ g$ of wet weight $)$, and Denman et al. (2007) in steers $\left(10^{8}\right.$ to $10^{9}$ copies $\left./ \mathrm{mL}\right)$. The low $\mathrm{mcr} A$ transcript numbers observed in the current study could be related to amplification biases. Indeed, because $m c r A$ transcripts were less abundant in the total RNA extracts, it may be possible that they were less accessible to the DNA-polymerase due to a dilution effect.

Protozoa. For a more accurate quantification, protozoa were quantified using standards made with $18 \mathrm{~S}$ rRNA fragments and genomic DNA extracted from preparations with known cell number. Independent of the type of diet fed to cows, the protozoa numbers were greatest when expressed as 18S rRNA copies compared to when they were expressed as cell numbers (8.35 vs. $6.50 \mathrm{log}$ copies/g of DM; Table 5), which is a normal pattern because a single protozoan cell carries several copies of the 18S rRNA gene (Sylvester et al., 2005). Moreover, the protozoa can adjust their 18S rRNA gene copy number to adapt to ruminal environmental conditions, such as substrate availability (Sylvester et al., 2009).

\section{Effects of Increasing CS Proportion of the Diet on Active Microbial Populations}

Bacteria. As expected, total bacteria were more abundant $(P<0.05)$ in cows fed the $100 \%$ CS diet compared with cows fed 0\% CS and 50\% CS diets (Table 5). This was likely due to a greater bacterial proliferation caused by the supply of more readily fermentable carbohydrates (i.e., starch) in the $100 \%$ CS diet (Table 1). This higher bacterial population was partly due to an increment $(P<0.05)$ in the number of the amylolytic bacterial group Prevotella spp. Previous studies also reported an increase in amylolytic bacteria that grow rapidly when more fermentable substrate is available (Tajima et al., 2001; Callaway et al., 2010). Moreover, as already evidenced by previous studies that targeted DNA, the use of RNA confirms that Prevotella spp. is the dominant bacterial group within the rumen (Nagaraja and Titgemeyer, 2007; Bekele et al., 2010). Prevotella spp. is a well-known propionate-producing bacterial group via the succinate pathway (Purushe et al., 2010), and its proliferation in cows fed the $100 \%$ CS diet resulted in a greater ruminal propionate concentration at the expense of acetate and butyrate (Table 4). The lactate-utilizing bacterium $M$. elsdenii was numerically more abundant $(P=0.15)$ at $4 \mathrm{~h}$ after feeding in cows fed the $100 \%$ CS diet compared with cows fed the $0 \%$ CS diet. Higher numbers of $M$. elsdenii may be an indication of a greater lactate production at 4 $\mathrm{h}$ after feeding in cows fed the $100 \%$ CS diet, as this bacterium has been reported to metabolize up to 60 to $80 \%$ of ruminal lactate (Counotte et al., 1981) and is also known as the only bacterium that metabolizes lactate to propionate through the acrylate sink (Hino and Kuroda, 1993).

Replacing AS with CS in the diet reduced $(P<0.05)$ mean and minimum daily ruminal $\mathrm{pH}$ (Table 4) but did not affect the number of the cellulolytic bacteria $R$. albus and F. succinogenes (Table 5). However, although mean ruminal $\mathrm{pH}$ decreased $(P<0.05)$ from 6.47 before feeding to 5.69 after feeding (data not shown), $R$. albus numbers increased $(P<0.05)$ by $0.34 \log$ units in cows fed the $100 \%$ CS diet (Table 5 ). It is generally assumed that low ruminal $\mathrm{pH}$ has a negative effect on the growth of cellulolytic bacteria (Bekele et al., 2010; Fernando et al., 2010), but this has not been always the case, as others reported no change (Martin et al., 2001; Stevenson and Weimer, 2007) or even an increase (Olumeyan et al., 1986; Khafipour et al., 2009) in the number of cellulolytic bacteria. According to our findings and findings in the literature, it seems that the effect of diets on the growth of cellulolytic bacteria is variable and multifactorial because ruminal $\mathrm{pH}$, the capacity of the different species to adapt to dietary changes, and the interactions among different species are all factors that may account for the discrepancies between studies (Lettat, 2011).

Archaea and Protozoa. Archaea (at $0 \mathrm{~h}$ and mean) were more abundant $(P<0.05)$ in cows fed the $100 \%$ CS diet compared with cows fed the 0\% CS and $50 \%$ CS diets (Table 5). Similarly, their methanogenic activity at the 0-h sampling time estimated with the number of $m c r A$ transcripts was greatest $(P<0.05)$ for cows fed $100 \%$ CS diet compared with cows fed $0 \%$ CS and $50 \%$ CS $(P=0.10)$ diets. At $4 \mathrm{~h}$ after feeding, archaeal methanogenic activity was similar among diets, but the mean activity tended $(P=0.10)$ to be greater in cows fed $100 \%$ CS diet than in cows fed $50 \%$ CS diet. For cows fed the $100 \%$ CS diet, archaeal methanogenic activity decreased $(P<0.05)$ after feeding, but their 


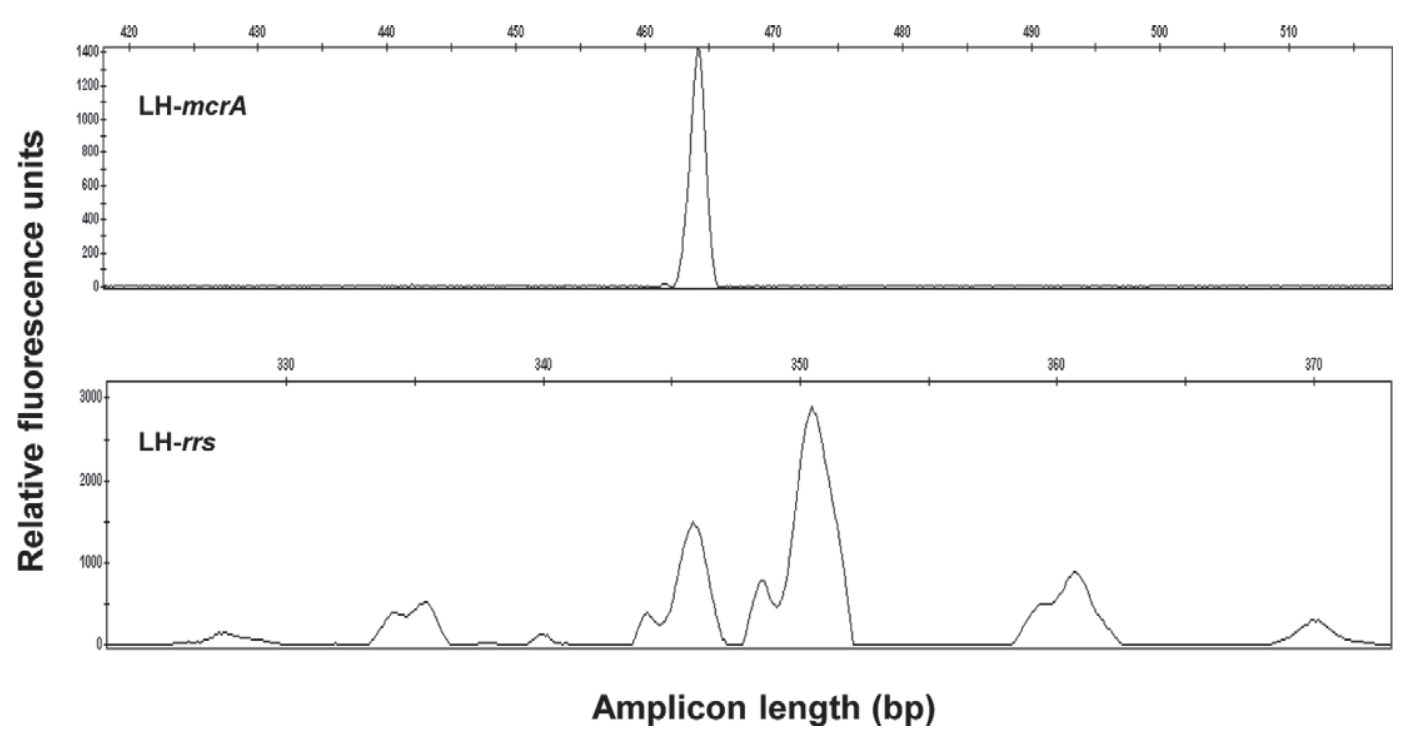

Figure 1. Electropherograms of DNA fragments from Archaea [length heterogeneity-methyl coenzyme-M reductase (LH- $m c r A)$ and bacteria [length heterogeneity-small ribosomal subunit (LH-rrs)] within the rumen of a single lactating cow fed the 100\% corn silage (CS) diet.

number remained unaffected. This was probably due to the decrease in ruminal $\mathrm{pH}(-0.78 \mathrm{pH}$ units; $P<0.05)$ and is supported by previous reports that showed that low ruminal $\mathrm{pH}$ impairs methanogens activity but not their growth (Van Kessel and Russell, 1996; Hook et al., 2011a).

Contrary to our observations on bacteria and Archaea, increasing the proportion of CS in the diet was accompanied by a decrease in the protozoal population, which is in line with the decrease in butyrate concentration (Table 4), as protozoa are known to be an important contributor to butyrate production within the rumen (Eugène et al., 2004). When expressed as 18S rRNA copies, the protozoal number was reduced $(P<0.05)$ in cows fed $100 \%$ CS compared with cows fed the 0\% CS and $50 \%$ CS diets. Moreover, the protozoal population (at $0 \mathrm{~h}$ and mean) tended $(P=0.10)$ to be lower in cows fed the $50 \%$ CS diet compared with cows fed the $0 \%$ CS diet. When expressed as cell number, feeding cows the $100 \%$ CS diet decreased $(P<0.05)$ the number of protozoa compared with feeding $0 \%$ CS and $50 \%$ CS diets. To the best of our knowledge, studies dealing with the effects of forage type on the protozoal population are very scarce, and those reporting diet change effects have been inconsistent and revealed either an increase (Hook et al., 2011a), a decrease (Khafipour et al., 2009), or no change (Benchaar et al., 2007) in the protozoal population. One possible explanation for the decrease in protozoa number in the present study could be a toxic effect of propionate associated with a low ruminal $\mathrm{pH}$ (minimum $\mathrm{pH}=5.66$; Table 4 ), as previously suggested (Fonty et al., 1995; Lettat, 2011).

\section{Effects of Increasing CS Proportion of the Diet on Microbial Diversity}

The LH-PCR fingerprint method used to characterize the bacterial community detected a total of 56 raw peaks. An iterative process of standardization (Dunbar et al., 2001) was applied so that the total peak height reflects an equivalent amount for each profile. This process ensures eliminating peaks with low original percentages (less than 2.5\%). The standardization reduced the number to 26 true comparable peaks of specific amplicons with a length ranging from 327 to 370 base pairs.

Compared with Bacteria, only 1 single peak (464 bp; Figure 1) was observed for Archaea using LHmcrA, which means that archaeal community is less diverse than the bacterial one (Aller and Kemp, 2008). Moreover, as recently pointed out in a study on swine manure (Barret et al., 2012), our results showed that the LH-PCR technique is not sensitive enough to study the archaeal species structure and diversity within the rumen compared with DGGE and clone library construction (Zhou et al., 2009; Popova et al., 2011). According to recent reports on swine manure (Gagnon et al., 2011; Barret et al., 2012), the 464-bp amplicon could be identified as Methanobrevibacter spp., which is consistent with numerous reports that showed the dominance of Methanobrevibacter within the rumen (Hook et al., 2011a; Zhou et al., 2011).

Principal component analysis allows identification of the most important directions to explain the variation in a multivariate data matrix in a graphical plot. Thus, 


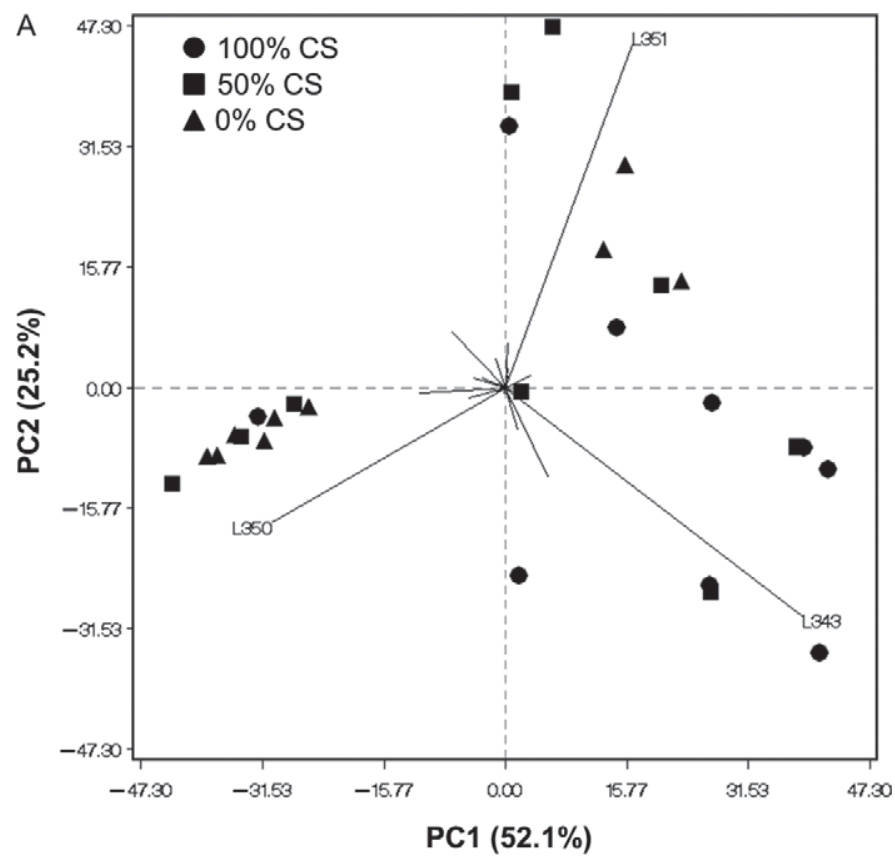

B

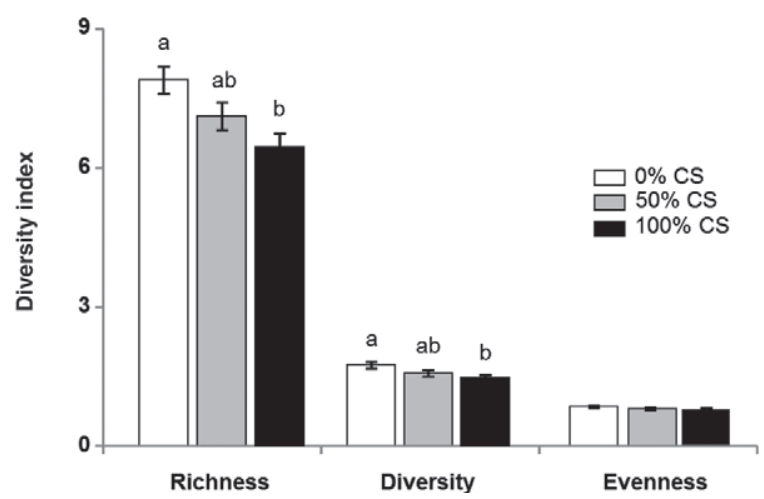

Figure 2. (A) Principal component (PC) analysis ordination of bacterial length (L) heterogeneity-small ribosomal subunit amplicons for samples collected from lactating cows fed diets with 0,50 , or $100 \%$ corn silage (CS). The percentage of total variance accounted for by each of the 2 principal components (PC1 and $\mathrm{PC} 2)$ is shown in parentheses. (B) Diversity indices of the bacterial community from lactating cows fed diets with 0, 50, or $100 \%$ CS. Error bars represent SEM. Lowercase letters $(\mathrm{a}, \mathrm{b})$ indicate significant differences $(P \leq 0.05)$ among diets.

PCA was used to visualize how the bacterial communities are affected when cows were fed different proportions of CS. The first 2 principal components explain $77.3 \%$ of the total variance (Figure 2A). According to the PCA analysis, the 343-, 350-, and 351-bp amplicons seem to be the most important. Moreover, the 343- and 350-bp amplicons were related to the 100 and $0 \%$ CS diets, respectively. Using the indicator species analysis, which allows identification of amplicons responsible for differences among groups (Dufrêne and Legendre, 1997), we observed a higher abundance of the 334-, 340-, and 370-bp amplicons in cows fed the 0\% CS diet, whereas the 327-, 343-, and 362-bp amplicons were more represented in those fed the $100 \%$ CS diet (Table 6). The diversity indices calculated from the LH-rrs fingerprints revealed that feeding the $100 \% \mathrm{CS}$ diet decreased $(P<$ $0.05)$ the bacterial community richness (6.44 vs. 7.89) and diversity (1.47 vs. 1.75; Figure 2B). The evenness remained similar among diets, suggesting that the relative abundance of the different species making up the richness of the bacterial community was similar. In line with previous reports, this study confirms that providing more readily fermentable carbohydrates decreases the bacterial richness and diversity (Khafipour et al., 2009; Hook et al., 2011b).

\section{Microbial Population Shifts and Ruminal Methanogenesis}

Results of the current study revealed that increasing starch supply via increasing the proportion of CS in the diet reduced $\mathrm{CH}_{4}$ production (L/ $\mathrm{kg}$ of DMI). Our results are in line with previous reports, confirming that ruminal methanogenesis is not strongly linked to archaeal number (Popova et al., 2011; Morgavi et al., 2012). Popova et al. (2011) reported that methanogenesis reduction in feedlot bulls fed a starch-rich diet supplemented with lipids was associated with a decrease in the archaeal methanogenic activity. This is in opposition to the findings of the present study, where a greater archaeal methanogenic activity was associated with a reduction in $\mathrm{CH}_{4}$ production $(\mathrm{L} / \mathrm{kg}$ of DMI). This discrepancy may be explained by the experimental conditions and the methodology used by Popova et al. (2011) for RNA extraction and mcrA quantification. Compared with our work, in the study by Popova et al. (2011), ruminal content was collected from slaughtered animals (after $24 \mathrm{~h}$ of fasting) and archaeal methanogenic activity was estimated using a relative quantification procedure.

In the present study, feeding the $100 \%$ CS diet decreased the number of protozoa, which is consistent with the lower $\mathrm{CH}_{4}$ production (L/kg of DMI) observed. Several studies also reported lower $\mathrm{CH}_{4}$ production when the number of protozoa decreased (Morgavi et al., 2010; Patra and Yu, 2012). Because protozoa are important hydrogen producers, a decrease in the transfer of hydrogen between the protozoa and the methanogens is probably at the origin of the observed reduction in ruminal methanogenesis (Martin et al., 2010; Morgavi et al., 2012). Moreover, feeding a $100 \%$ CS diet increased the number of total bacteria and the propionate-producing group Prevotella spp. as well as propionate concentration. These microbial and fer- 
Table 6. Indicator value (\%) of the bacterial length heterogeneity-small ribosomal subunit fingerprints from lactating cows fed diets with 0,50 , or $100 \%$ corn silage (CS)

\begin{tabular}{lccccc}
\hline & \multicolumn{5}{c}{ Treatment $^{2}$} \\
Amplicons \\
\cline { 2 - 4 } (bp) & $0 \%$ CS & $50 \%$ CS & $100 \%$ CS & SD & $P_{\text {-value }}{ }^{3}$ \\
\hline 327 & 0 & 0 & $\mathbf{3 3}$ & 7.4 & 0.08 \\
334 & $\mathbf{4 0}$ & 10 & 0 & 8.5 & 0.06 \\
340 & $\mathbf{3 3}$ & 0 & 0 & 7.3 & 0.08 \\
343 & 4 & 12 & $\mathbf{4 6}$ & 7.4 & 0.02 \\
362 & 1 & 7 & $\mathbf{4 6}$ & 8.7 & 0.03 \\
370 & $\mathbf{4 1}$ & 31 & 0 & 7.4 & 0.07 \\
\hline
\end{tabular}

${ }^{1}$ Indicator value $(\mathrm{IV})=$ relative abundance $\times$ relative frequency. Maximum IV for each amplicon is indicated in bold.

${ }^{2} 0 \% \mathrm{CS}=$ diet with $0 \%$ corn silage; $50 \% \mathrm{CS}=$ diet with $28.2 \%$ corn silage; $100 \% \mathrm{CS}=$ diet with $56.4 \%$ corn silage.

${ }^{3}$ Indicator values were tested for significance using a Monte Carlo technique.

mentation shifts represent competitive pathways that divert away hydrogen from methanogenesis, and could therefore explain the observed reductions in $\mathrm{CH}_{4}(\mathrm{~L} /$ $\mathrm{kg}$ of DMI) production (Martin et al., 2010; Morgavi et al., 2010).

Regarding the microbial structure, previous studies reported a decrease in $\mathrm{CH}_{4}$ production when the archaeal richness and diversity were reduced (Zhou et al., 2009; Popova et al., 2011). Although our attempt to estimate archaeal diversity was unsuccessful using the LH-PCR technique, the present study suggests that a less diverse bacterial community may result in lower $\mathrm{CH}_{4}$ production. As evidenced by indicator species analysis and multi-response permutation procedure analyses, feeding the $100 \%$ CS diet affected the bacterial community composition and, therefore, the fermentation pathways compared with feeding the $0 \%$ CS diet. The identification of the amplicons revealed in the current study, and especially those highly represented in cows fed the 0\% CS (334-, 340-, and 370-bp) and the $100 \%$ CS (327-, 343-, and 362-bp) diets, may contribute to enhancing our understanding of how the bacterial community is affected by dietary changes and enabling prediction of $\mathrm{CH}_{4}$ response and, hence, the development of more robust mitigation strategies.

\section{CONCLUSIONS}

This work aimed to investigate how the active microbial communities are affected by replacing AS with CS in dairy cow diets. Increasing the CS proportion in the diet (i.e., increasing starch supply) reduced the richness and the diversity of the bacterial community but increased the number of total bacteria and Prevotella spp., and favored propionate production. In this study, $\mathrm{CH}_{4}$ reduction can be linked to the decrease in protozoa but not to Archaea number or methanogenic activity that were increased by the $100 \%$ CS diet. Based on mi- crobial and fermentation changes, this study shows that the use of cDNA-based quantitative PCR to estimate archaeal growth and activity is not reliable enough to reflect changes in ruminal methanogenesis. In addition to the shifts observed within the bacterial community, a modification in the archaeal community structure toward less efficient $\mathrm{CH}_{4}$-producing species is probable and deserves further investigation.

\section{ACKNOWLEDGMENTS}

We are grateful to the Dairy and Swine Research Centre (Agriculture and Agri-Food Canada, Sherbrooke, Canada) staff, including L. Croteau (technical support), S. Méthot (help with statistical analyses), N. Gagnon (help with LH-PCR), and the barn crew (care of the cows). A. Lettat was a recipient of a postdoctoral fellowship from the National Science and Engineering Research Council of Canada (Ottawa, Canada). This study was funded by a grant (Dairy Research Cluster) from Agriculture and Agri-Food Canada (Ottawa, Canada), Dairy Farmers of Canada (Ottawa, Canada) and Canadian Dairy Commission (Ottawa, Canada).

\section{REFERENCES}

Aller, J. Y., and P. F. Kemp. 2008. Are Archaea inherently less diverse than bacteria in the same environments? FEMS Microbiol. Ecol. 65:74-87.

Barret, M., N. Gagnon, B. Morissette, E. Topp, M. Kalmokoff, S. P. J. Brooks, F. Matias, D. I. Massé, L. Masse, and G. Talbot. 2012. Methanoculleus spp. as a biomarker of methanogenic activity in swine manure storage tanks. FEMS Microbiol. Ecol. 80:427-440.

Bekele, A. Z., S. Koike, and Y. Kobayashi. 2010. Genetic diversity and diet specificity of ruminal Prevotella revealed by $16 \mathrm{~S}$ rRNA genebased analysis. FEMS Microbiol. Lett. 305:49-57.

Benchaar, C., and H. Greathead. 2011. Essential oils and opportunities to mitigate enteric methane emissions from ruminants. Anim. Feed Sci. Technol. 166-167:338-355.

Benchaar, C., H. V. Petit, R. Berthiaume, D. R. Ouellet, J. Chiquette, and P. Y. Chouinard. 2007. Effects of essential oils on digestion, ruminal fermentation, rumen microbial populations, milk produc- 
tion, and milk composition in dairy cows fed alfalfa silage or corn silage. J. Dairy Sci. 90:886-897.

Benchaar, C., G. A. Romero-Pérez, P. Y. Chouinard, F. Hassanat, M. Eugène, H. V. Petit, and C. Côrtes. 2012. Supplementation of increasing amounts of linseed oil to dairy cows fed total mixed rations: Effects on digestion, ruminal fermentation characteristics, protozoal populations, and milk fatty acid composition. J. Dairy Sci. 95:4578-4590.

Boadi, D., C. Benchaar, J. Chiquette, and D. Massé. 2004. Mitigation strategies to reduce enteric methane emissions from dairy cows: Update review. Can. J. Anim. Sci. 84:319-335.

Callaway, T. R., S. E. Dowd, T. S. Edrington, R. C. Anderson, N. Krueger, N. Bauer, P. J. Kononoff, and D. J. Nisbet. 2010. Evaluation of bacterial diversity in the rumen and feces of cattle fed different levels of dried distillers grains plus solubles using bacterial tag-encoded FLX amplicon pyrosequencing. J. Anim. Sci. 88:3977-3983.

Canadian Council on Animal Care (CCAC). 1993. Guide to the Care and Use of Experimental Animals. Vol. 1. 2nd ed., CCAC, Ottawa, ON, Canada.

Chaucheyras-Durand, F., S. Masséglia, G. Fonty, and E. Forano. 2010. Influence of the composition of the cellulolytic flora on the development of hydrogenotrophic microorganisms, hydrogen utilization, and methane production in the rumens of gnotobiotically reared lambs. Appl. Environ. Microbiol. 76:7931-7937.

Counotte, G. H. M., R. A. Prins, R. H. A. M. Janssen, and M. J. A. deBie. 1981. Role of Megasphaera elsdenii in the fermentation of DL- $\left[2-{ }^{13} \mathrm{C}\right]$ lactate in the rumen of dairy cattle. Appl. Environ. Microbiol. 42:649-655.

de la Cruz-Leyva, M. C., M. Zamudio-Maya, A. I. Corona-Cruz, J. U. González-de la Cruz, and R. Rojas-Herrera. 2011. A method for isolating RNA from metabolically active bacterial flora associated with octopus. Lett. Appl. Microbiol. 53:8-13.

Denman, S. E., N. W. Tomkins, and C. S. McSweeney. 2007. Quantitation and diversity analysis of ruminal methanogenic populations in response to the antimethanogenic compound bromochloromethane. FEMS Microbiol. Ecol. 62:313-322.

Dufrêne, M., and P. Legendre. 1997. Species assemblages and indicator species: The need for a flexible asymmetrical approach. Ecol. Monogr. 67:345-366.

Dunbar, J., L. O. Ticknor, and C. R. Kuske. 2001. Phylogenetic specificity and reproducibility and new method for analysis of terminal restriction fragment profiles of $16 \mathrm{~S}$ rRNA genes from bacterial communities. Appl. Environ. Microbiol. 67:190-197.

Edwards, J. E., S. A. Huws, E. J. Kim, and A. H. Kingston-Smith. 2007. Characterization of the dynamics of initial bacterial colonization of nonconserved forage in the bovine rumen. FEMS Microbiol. Ecol. 62:323-335.

Eugène, M., H. Archimède, B. Michalet-Doreau, and G. Fonty. 2004. Effects of defaunation on microbial activities in the rumen of rams consuming a mixed diet (fresh Digitaria decumbens grass and concentrate). Anim. Res. 53:187-200.

Fernando, S. C., H. T. Purvis, F. Z. Najar, L. O. Sukharnikov, C. R. Krehbiel, T. G. Nagaraja, B. A. Roe, and U. DeSilva. 2010. Rumen microbial population dynamics during adaptation to a highgrain diet. Appl. Environ. Microbiol. 76:7482-7490.

Fonty, G., J.-P. Jouany, E. Forano, and P. Gouet. 1995. L'écosysteme microbien du réticulo-rumen. Pages 299-347 in Nutrition des Ruminants Domestiques, Ingestion et Digestion, R. Jarrige, Y. Ruckebusch, C. Demarquilly, M. H. Farce, M. Journet, ed. INRA, Paris, France.

Freitag, T. E., and J. I. Prosser. 2009. Correlation of methane production and functional gene transcriptional activity in a peat soil. Appl. Environ. Microbiol. 75:6679-6687.

Gagnon, N., M. Barret, E. Topp, M. Kalmokoff, D. Massé, L. Masse, and G. Talbot. 2011. A novel fingerprint method to assess the diversity of methanogens in microbial systems. FEMS Microbiol. Lett. 325:115-122.

Hassanat, F., R. Gervais, C. Julien, D. I. Massé, A. Lettat, P. Y. Chouinard, H. V. Petit, and C. Benchaar. 2013. Replacing alfalfa silage with corn silage in dairy cow diets: Effects on enteric methane production, ruminal fermentation, digestion, $\mathrm{N}$ balance, and milk production. J. Dairy Sci. 96:4553-4567. http://dx.doi. org/10.3168/jds.2012-6480.

Hino, T., and S. Kuroda. 1993. Presence of lactate dehydrogenase and lactate racemase in Megasphaera elsdenii grown on glucose or lactate. Appl. Environ. Microbiol. 59:255-259.

Hook, S. E., M. Steele, K. Northwood, A.-D. Wright, and B. McBride. 2011a. Impact of high-concentrate feeding and low ruminal $\mathrm{pH}$ on methanogens and protozoa in the rumen of dairy cows. Microb. Ecol. 62:94-105.

Hook, S. E., M. A. Steele, K. S. Northwood, J. Dijkstra, J. France, A.-D. G. Wright, and B. W. McBride. 2011b. Impact of subacute ruminal acidosis (SARA) adaptation and recovery on the density and diversity of bacteria in the rumen of dairy cows. FEMS Microbiol. Ecol. 78:275-284.

Khafipour, E., S. Li, J. C. Plaizier, and D. O. Krause. 2009. Rumen microbiome composition determined using two nutritional models of subacute ruminal acidosis. Appl. Environ. Microbiol. 75:7115-7124.

Lassey, K. R. 2008. Livestock methane emission and its perspective in the global methane cycle. Aust. J. Exp. Agric. 48:114-118.

Lettat, A. 2011. Efficacité et mode d'action des bactéries propioniques et/ou lactiques pour prévenir l'acidose latente chez le ruminant. PhD Diss. École Doctorale SVSAE, Université Blaise Pascal-Clermont Ferrand II, France.

Lettat, A., P. Noziere, M. Silberberg, D. P. Morgavi, C. Berger, and C. Martin. 2012. Rumen microbial and fermentation characteristics are affected differently by bacterial probiotic supplementation during induced lactic and subacute acidosis in sheep. BMC Microbiol. 12:142.

Mackie, R. I., F. M. C. Gilchrist, A. M. Robberts, P. E. Hannah, and H. M. Schwartz. 1978. Microbiological and chemical changes in the rumen during the stepwise adaptation of sheep to high concentrate diets. J. Agric. Sci. 90:241-254.

Martin, C., L. Millet, G. Fonty, and B. Michalet-Doreau. 2001. Cereal supplementation modified the fibrolytic activity but not the structure of the cellulolytic bacterial community associated with rumen solid digesta. Reprod. Nutr. Dev. 41:413-424.

Martin, C., D. P. Morgavi, and M. Doreau. 2010. Methane mitigation in ruminants: From microbe to the farm scale. Animal 4:351-365.

McCune, B., and M. Mefford. 1999. Multivariate analysis of ecological data. PC-ORD for Windows. Version 4. MjM Software Design, Gleneden Beach, OR.

Mohammed, R., M. Zhou, K. M. Koenig, K. A. Beauchemin, and L. L. Guan. 2011. Evaluation of rumen methanogen diversity in cattle fed diets containing dry corn distillers grains and condensed tannins using PCR-DGGE and qRT-PCR analyses. Anim. Feed Sci. Technol. 166:122-131.

Morgavi, D. P., E. Forano, C. Martin, and C. J. Newbold. 2010. Microbial ecosystem and methanogenesis in ruminants. Animal 4:1024-1036.

Morgavi, D. P., C. Martin, J.-P. Jouany, and M. J. Ranilla. 2012. Rumen protozoa and methanogenesis: Not a simple cause-effect relationship. Br. J. Nutr. 107:388-397.

Mosoni, P., F. Chaucheyras-Durand, C. Béra-Maillet, and E. Forano. 2007. Quantification by real-time PCR of cellulolytic bacteria in the rumen of sheep after supplementation of a forage diet with readily fermentable carbohydrates: Effect of a yeast additive. J. Appl. Microbiol. 103:2676-2685.

Mosoni, P., C. Martin, E. Forano, and D. P. Morgavi. 2011. Long-term defaunation increases the abundance of cellulolytic ruminococci and methanogens but does not affect the bacterial and methanogen diversity in the rumen of sheep. J. Anim. Sci. 89:783-791.

Nagaraja, T. G., and E. C. Titgemeyer. 2007. Ruminal acidosis in beef cattle: The current microbiological and nutritional outlook. J. Dairy Sci. 90(E. Suppl.):E17-E38.

Nunoura, T., H. Oida, T. Toki, J. Ashi, K. Takai, and K. Horikoshi. 2006. Quantification of mcrA by quantitative fluorescent PCR in sediments from methane seep of the Nankai Trough. FEMS Microbiol. Ecol. 57:149-157. 
Ohene-Adjei, S., A. V. Chaves, T. A. McAllister, C. Benchaar, R. M. Teather, and R. J. Forster. 2008. Evidence of increased diversity of methanogenic Archaea with plant extract supplementation. Microb. Ecol. 56:234-242.

Olumeyan, D. B., T. G. Nagaraja, G. W. Miller, R. A. Frey, and J. E. Boyer. 1986. Rumen microbial changes in cattle fed diets with or without salinomycin. Appl. Environ. Microbiol. 51:340-345.

Ozutsumi, Y., K. Tajima, A. Takenaka, and H. Itabashi. 2006. Realtime PCR detection of the effects of protozoa on rumen bacteria in cattle. Curr. Microbiol. 52:158-162.

Patra, A. K., and Z. Yu. 2012. Effects of essential oils on methane production, fermentation, abundance and diversity of rumen microbial populations. Appl. Environ. Microbiol. 78:4271-4280.

Popova, M., C. Martin, M. Eugène, M. M. Mialon, M. Doreau, and D. P. Morgavi. 2011. Effect of fibre- and starch-rich finishing diets on methanogenic Archaea diversity and activity in the rumen of feedlot bulls. Anim. Feed Sci. Technol. 166-167:113-121.

Purushe, J., D. Fouts, M. Morrison, B. White, R. Mackie, N. A. C. R. Bacteria, P. Coutinho, B. Henrissat, and K. Nelson. 2010. Comparative genome analysis of Prevotella ruminicola and Prevotella bryantii: Insights into their environmental niche. Microb. Ecol. 60:721-729.

Sheridan, G. E. C., C. I. Masters, J. A. Shallcross, and B. M. Mackey. 1998. Detection of mRNA by reverse transcription-PCR as an indicator of viability in Escherichia coli cells. Appl. Environ. Microbiol. 64:1313-1318.

Stevenson, D. M., and P. Weimer. 2007. Dominance of Prevotella and low abundance of classical ruminal bacterial species in the bovine rumen revealed by relative quantification real-time PCR. Appl. Microbiol. Biotechnol. 75:165-174

Suzuki, M., M. S. Rappe, and S. J. Giovannoni. 1998. Kinetic bias in estimates of coastal picoplankton community structure obtained by measurements of small-subunit rRNA gene PCR amplicon length heterogeneity. Appl. Environ. Microbiol. 64:4522-4529.
Sylvester, J. T., S. K. R. Karnati, B. A. Dehority, M. Morrison, G L. Smith, N. R. St-Pierre, and J. L. Firkins. 2009. Rumen ciliated protozoa decrease generation time and adjust $18 \mathrm{~S}$ ribosomal DNA copies to adapt to decreased transfer interval, starvation, and monensin. J. Dairy Sci. 92:256-269.

Sylvester, J. T., S. K. R. Karnati, Z. Yu, M. Morrison, and J. L. Firkins. 2004. Development of an assay to quantify rumen ciliate protozoal biomass in cows using real-time PCR. J. Nutr. 134:3378-3384.

Sylvester, J. T., S. K. R. Karnati, Z. Yu, C. J. Newbold, and J. L. Firkins. 2005. Evaluation of a real-time PCR assay quantifying the ruminal pool size and duodenal flow of protozoal nitrogen. J. Dairy Sci. 88:2083-2095.

Tajima, K., R. I. Aminov, T. Nagamine, H. Matsui, M. Nakamura, and Y. Benno. 2001. Diet-dependent shifts in the bacterial population of the rumen revealed with real-time PCR. Appl. Environ. Microbiol. 67:2766-2774.

Thauer, R. K. 1998. Biochemistry of methanogenesis: A tribute to Marjory Stephenson: 1998 Marjory Stephenson Prize Lecture. Microbiology 144:2377-2406.

Van Kessel, J. A. S., and J. B. Russell. 1996. The effect of pH on ruminal methanogenesis. FEMS Microbiol. Ecol. 20:205-210.

Wanapat, M., and A. Cherdthong. 2009. Use of real-time PCR technique in studying rumen cellulolytic bacteria population as affected by level of roughage in Swamp Buffalo. Curr. Microbiol. $58: 294-299$.

Zhou, M., Y. H. Chung, K. A. Beauchemin, L. Holtshausen, M. Oba, T. A. McAllister, and L. L. Guan. 2011. Relationship between rumen methanogens and methane production in dairy cows fed diets supplemented with a feed enzyme additive. J. Appl. Microbiol. 111:1148-1158.

Zhou, M., E. Hernandez-Sanabria, and L. L. Guan. 2009. Assessment of the microbial ecology of ruminal methanogens in cattle with different feed efficiencies. Appl. Environ. Microbiol. 75:6524-6533. 